\title{
Workload assessment on foundry SME to enhance productivity using full time equivalent
}

\author{
Amarria Dila Sari, Fajri Hardiansa, and Muhamad Ragil Suryoputro \\ Departement of Industrial Engiineering, Islamic University of Indonesia, Indonesia
}

\begin{abstract}
Aluminium SME aims to increase the production amount by producing wok as much as 300 Units. The problem is workload analysis of operator on the wok production line in the wok foundry SME as well as the production cycle-making cycle time and analyze the workload received by the operator when producing 300 woks using the full time equivalent (FTE) method. This study aims to measure the workload of each division worker in the production process with a total of 13 workers observed. This study provides a work division recommendation based on the workload that has been carefully examined. This research involves percentage of workload effectiveness and the wages of workers. In lathe division have overload workload. While the printing division, melting inspection division, packaging and transportation division including normal workload category and the percentage of good work effectiveness. The result provides recommendations for the addition of 2 workers in each division that includes the category of overload of the lathe division with the number of initial workers as many as 13 workers to 15 workers. In the last stage perform a simulation by comparing the system of prefix work and proposal. The simulation results obtained with the initial work system to get an average of 223 woks / day. Meanwhile, for the proposed work system to get an average output of 291 woks.
\end{abstract}

\section{Introduction}

Determination of the amount of labour is sometimes done only based on estimates, however it would result in incompatibilities use of human resources in the company [1]. Every worker has the responsibility to complete a number of jobs within a certain time which is a workload for the workers [2]. Workload analysis aims to determine how the number of workers required to complete a job and how much load the appropriate delegated to one worker [3]. Workload is the number of job targets or target outcomes to be achieved within a certain time unit [4]. Workload is also defined as a management technique systematically performed to obtain information about the effectiveness and efficiency of the organization based on the work volume [3]. The determination of workload is based on the employee's ability to perform any standard tasks. The standards of employees average ability refers to the standard capabilities showing the size of the average energy given by an employee or group to obtain a unit of outcome [4]. This research will be used method of Full Time Equivalent supported by the stopwatch method to determine standard time of a job.

Full Time Equivalent (FTE) aims to change the hours of workload to the number of people needed to complete a particular job [5]. This FTE method will provide information on the allocation of employee resources to complete a job and time in each work activity that can be * Corresponding author: amarria@uii.ac.id seen based on the results of the measurement of work time directly with the Stopwatch method. The Stopwatch method is a direct observed work-time measurement commonly applied to jobs that are generally short-lived and repetitive [6].

Related research to the workload has been carried out through various methods, for example the study of mental workload using NASA-Task Load Index (TLX) for industrial employees conducted by $[7,8]$. Meanwhile, the study of physical workload for laundry worker using cardio vascular load method has been discussed by Sari [9]. Research regarding workload using workload indicators of staffing need (WISN) in Namibia [10], WISN in staffing nurse [11], also WISN Method for staffing in family health care [12]. Furthermore, research related workload and foundry has been conducted by Sharma \& Singh [13], regarding work-related musculoskeletal disorders, job stressors and gender responses in foundry industry. The study concerning implementation of lean manufacturing principles in Foundries [14]. Standard time measurement method with a stopwatch can result in an accurate time with some activities if it is followed by a clear working order [15].

Based on the research workload that has been done on previous researcher it is necessary to conduct further research on workload measurement of workers in Foundry SME at wok production line at Bantul Yogyakarta (Figure 1). Aluminum SME is a home 
manufacturing industry that produces kitchen utensils. The determination of workload is based on the standard of worker's ability to perform its duties [15]. Excessive workload can cause work atmosphere that is less comfortable for workers because it can trigger the emergence of work stress faster [16]. Therefore, must determine many workers based on production requirements so that every job done to get optimal results so that the results of improvement can be a reference or guidance to recruit the number of employees who must be accepted. The work load that has been obtained will then be converted to worker incentives. From the workload it can be known how much appropriate salary for the worker. As well as applying simulations to prefix work systems and recommendations to fit the actual work system [17].

\section{Literature Review}

The workload is the calculation and comparison between the needs of human resources or capacity required and the real capability of the human $([18,19])$. Besides that, according to [20] workload not only calculate the time spent for productive work but also includes the calculation about human factors, such as fatigue, personal needs, and looseness factor.

One method that can be used to measure the workload is a full time equivalent. Full time equivalent employees equal the number of employees on full-time schedules plus the number of employees on part-time schedules converted to a full-time basis. The number of full time equivalent employees in each industry is the product of the total number of employees and the ratio of average weekly hours per employee on full-time schedules. An industry's full-time equivalent employment will be less than the number of its employees on full- and part-time schedules, unless it has no part-time employees. The full time equivalent could be defined as the total amount of time needed by the worker to perform all the job in a certain time that analysed [18].

\section{Method}

\subsection{Object and subject}

Research was conducted at the Wok Aluminium SME with a variety job including melting, printing, thought, latheing, inspection, packaging, transpenim as shown in Figures 1 - 4. While in each bank two employees have been selected in accordance with some criteria including male, aged between 20 years to 35 years old, volunteer, with a minimum work experience is one year. Meanwhile, employees were selected based on the management, recommendation in consideration to the skills and effort.

\subsection{Research Procedure}

Research procedures were divided into the following phases: a. Preparation Phase: The research preparation was an early stage prior to the study. determining the observation location; setting the standard time measurement form; preparing the tools used as a stopwatch and recording devices; and preparing the workforce to be observed.

b. Determination of Allowance: At this stage will be determined allowance consisting of leniency for personal needs, allowance to eliminate the sense of fatique, allowance for inevitable obstacles and work environment.

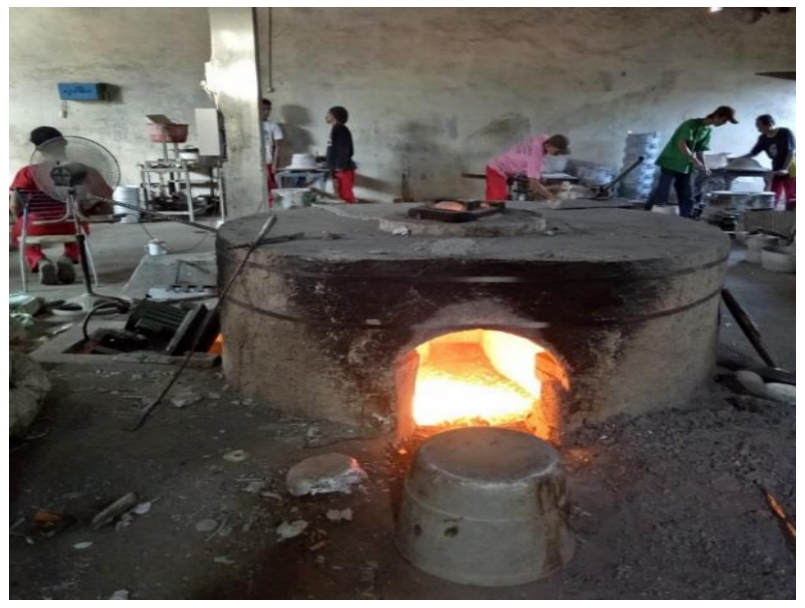

Fig 1. Melting division

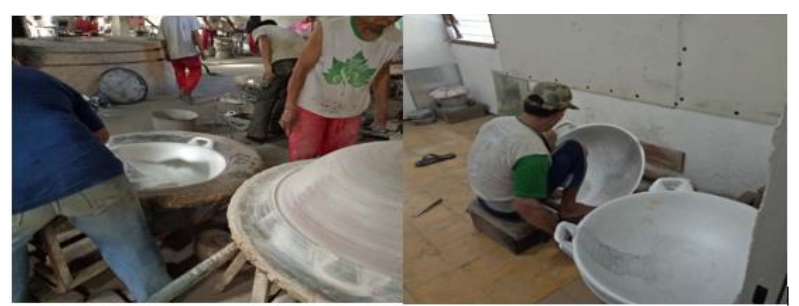

Fig 2. Printing and measurement divisions
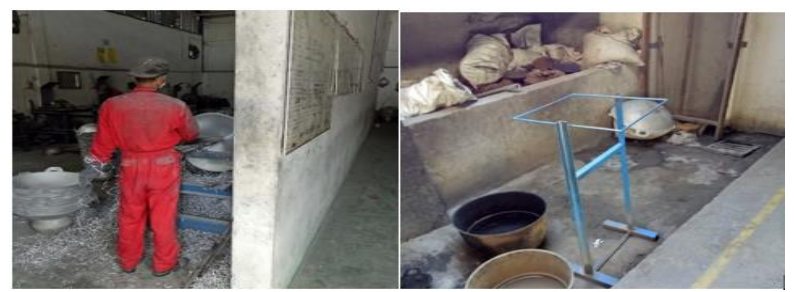

Fig 3. Lathe and inspection divisions

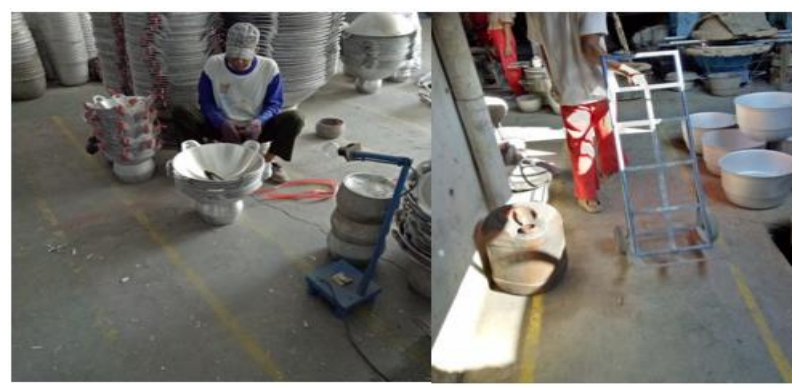

Fig 4. Packaging and transportation divisions

c. Determining Effective Working Time. At this stage will be determined effective working time is the number of days in the calendar minus holidays and 
leave. After the determination of the effective working days later determined the effective working hours per year: Total workday in hours multiplied by the percentage of the effectiveness of the work.

d. Workload Calculation. Full Time Equivalent aims to simplify work measurements by changing the hours of workload to the number of people needed to complete a particular job. The implication of FTE value is divided into 3 types: overload, normal, and underload. Based on the workload analysis guidance, the total FTE index value above 1.28 is considered overload, between 1 to 1.28 is considered normal whereas if the FTE index value is between 0 to 0.99 Considered underload or workload is still less than the maximum [21].

e. Manpower Requirement Calculation: At this stage, the optimal labor requirement is calculated for a certain position with the task approach per job assignment obtained from the calculation of the number of task completion times for one year divided by the number of working hours effective for one year. This approach is the result of FTE calculations to measure workload.

f. Effectiveness Persetanse Workload Calculation and Actual Work Hours. Every employee is also entitled to a break and time for worship. Working Hours are time to do work, can be done during the day and/or at night [1]. To determine the time can be done by calculating the time division work or individual work time of the worker. For employees with 5 working days per week, worker's obligation to work is 8 hours / day and 40 hours/week.

g. System Modeling: Simulation is an imitation of a facility or process of an operation, usually using a computer [22]. Software used is flexim software, Flexsim is a set of 3-D computer image processing technology, simulation techniques, artificial intelligence technology, and data handling techniques [17].

\section{Result and Discussion}

Respondents in this study were 13 male operators, aged between 24-34 years. At the level of education as many as eight workers have a high school education, while for 5 other workers is junior high. Work Experience owned by each operator is between 1 to 4 years. Based on Table 1, it can be seen that the amount of allowance for the wok production employee is $15 \%$. Allowance is the adjustment done to the normal time to obtain the standard time for the purpose to recover the lost time due to personal needs, fatigue, and unavoidable delays [5].

\subsection{Workload Measurement}

The results of the calculation of adequacy and uniformity of data can be explained that the data collected is enough with the value of $\mathrm{N}^{\prime}<\mathrm{N}$ for all elements of the activity. Meanwhile, uniformity calculation data can also be concluded that all the data entered in the control limits, so that the data collected is already eligible to be counted workload. The calculation of workload with the full time equivalent method on the production of pan is shown in Table 2.

Table 1. Allowance

\begin{tabular}{llc}
\hline Allowance Factor & Category & $\mathbf{\%}$ \\
\hline Energi Release & Low & 3 \\
Work Postur & Standing on two legs & 2 \\
Work Movement & Normal & 1 \\
Eye Fatigue & View is disconnected & 2 \\
Temperature & Medium & 2 \\
Environment & Circumstances exceptional & 2 \\
Atmosphere & Adequete & 2 \\
Personal needs & Male & 1 \\
\hline Total & & $\mathbf{1 5}$ \\
\hline
\end{tabular}

Table 2. Recapitulation workload per division

\begin{tabular}{|c|c|c|c|c|c|c|c|c|c|c|c|c|c|c|}
\hline \multicolumn{8}{|c|}{ Existing } & \multicolumn{7}{|c|}{ Recommendation } \\
\hline No & Div & \begin{tabular}{|l|} 
Work \\
Element
\end{tabular} & \begin{tabular}{|l} 
No of \\
Worker
\end{tabular} & $\begin{array}{l}\text { FTE } \\
\text { Ave }\end{array}$ & \begin{tabular}{|c|}
$\%$ \\
Wload
\end{tabular} & \begin{tabular}{|l|} 
Work \\
Hour \\
\end{tabular} & Remarks & No Div & \begin{tabular}{|l|} 
Work \\
Element
\end{tabular} & $\begin{array}{l}\text { No of } \\
\text { Worker }\end{array}$ & FTE Ave & $\%$ Wload & $\begin{array}{l}\text { Work } \\
\text { Hour }\end{array}$ & Remarks \\
\hline 1 & Melt & & 3 & \begin{tabular}{l|l|}
1 & 1.15 \\
\end{tabular} & 98 & 8 & Fit & \begin{tabular}{|l|l|}
1 & Melt \\
\end{tabular} & 3 & & 1.15 & 98 & 8 & Fit \\
\hline 2 & Print & & 6 & \begin{tabular}{l|l|}
3 & 1.04 \\
\end{tabular} & 88 & 7 & Fit & \begin{tabular}{|l|l|}
2 & Print \\
\end{tabular} & 6 & & \begin{tabular}{l|l|}
3 & 1.04 \\
\end{tabular} & 88 & 7 & Fit \\
\hline 3 & Grind & & 6 & \begin{tabular}{l|l|}
3 & 1.38 \\
\end{tabular} & 117 & 9.3 & Overload & 3 Grind & 6 & & $\begin{array}{l}4 \\
4 \quad 1.23 \\
\end{array}$ & 88. & 7 & Fit \\
\hline 4 & Lathe & & 9 & \begin{tabular}{l|l}
3 & 1.34 \\
\end{tabular} & 114 & 9.1 & Overload & 4 Lathe & 9 & & $\begin{array}{ll}4 & 1.18 \\
\end{array}$ & 85 & 7 & Fit \\
\hline 5 & Inspect & & 5 & 1 1.05 & 94 & 7.5 & Fit & 5 Inspect & 5 & & \begin{tabular}{l|l}
1 & 1.05 \\
\end{tabular} & 94 & 7.5 & Fit \\
\hline 6 & Packaging & & 7 & \begin{tabular}{l|l|l|}
1 & 1.11 \\
\end{tabular} & 94 & 7.5 & Fit & \begin{tabular}{|l|l|}
6 & Packaging \\
\end{tabular} & 7 & & \begin{tabular}{l|l|}
1 & 1.11 \\
\end{tabular} & 94 & 7.5 & Fit \\
\hline 7 & Transp & & 5 & 1 | 1.13 & 96 & 8 & Fit & \begin{tabular}{|l|l|}
7 & Transp \\
\end{tabular} & 5 & 1 & \begin{tabular}{l|l}
1 & 1.13 \\
\end{tabular} & 96 & 8 & Fit \\
\hline Total & & & 1 & 3 & & & & Total & & 15 & & & & \\
\hline
\end{tabular}

The full-time equivalent calculation for each division is only the smelting, printing, packaging, transport, and inspection division that has normal loads of 1.15, 1.04, $1.05,1.11$ and 1.13 since it is between 1.00 up to 1.28 . Meanwhile, the grinding division is in the category of overload because the value of FTE is above 1.28. The calculation of the effectiveness of the work issued in each division is only the smelting division, printing, packaging, inspection, and transportation, which has a normal load with a value between $80 \%-100 \%$ i.e. $97.70 \%, 88.14 \%$, $94.39 \%, 94.10 \%, 95.72 \%$. Meanwhile, in the other two divisions in the division of thinking and division is in the category of overload because the value of workload is above $100 \%$. Workloads charged to employees may occur under three conditions: normal workload (overwork), overload and underload [23]

Through good human resource planning, it can be seen how many human resources are available with the required human resources [24]. Therefore, it is of the problems found then get a recommendation addition of 1 worker in smelting division and division transportation whose value is in the normal category. The calculation of the effectiveness of work issued based on recommendations can be said to be normal workload of each division. This is because the effectiveness of the given workload is between $80 \%-100 \%$.

\subsection{Simulation Result}

The simulation technique is not an optimization process and does not produce an answer but only produces a set of outputs from the system under different conditions [17]. 


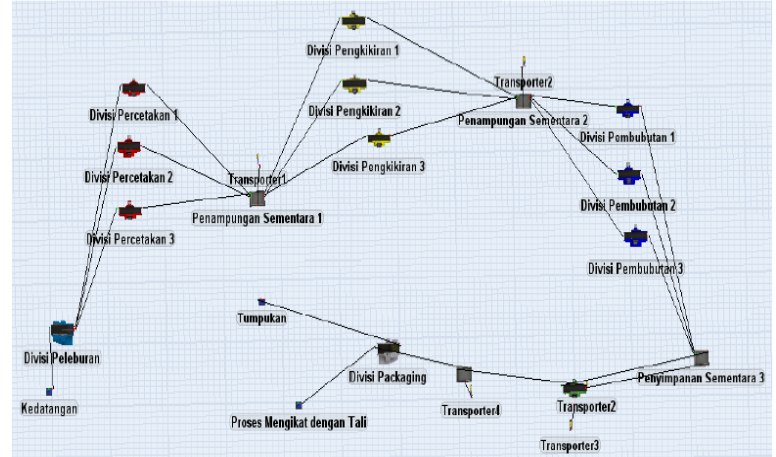

Fig 5. System modelling existing

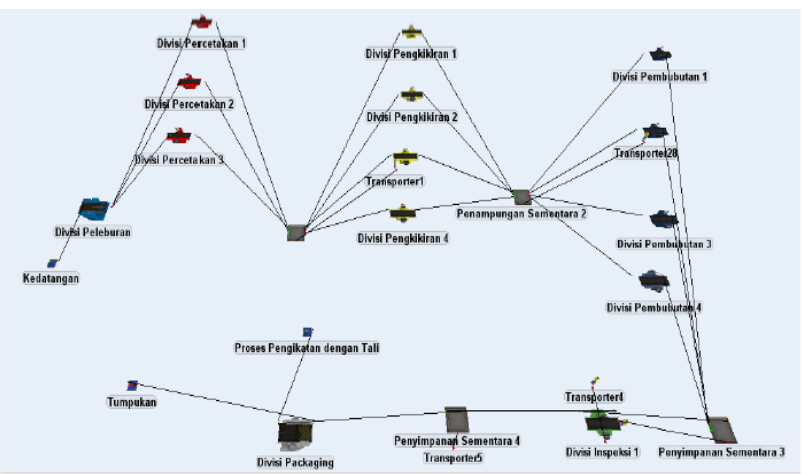

Fig 6. Proposed system modelling

Based on Figures 5 and 6, explaining the estimation simulation of the production process when performing production with workers and the available work system. In the simulation serves to estimate about the system under study and serves to estimate about the system created. In the simulation explains the stages of production of wok. The production process consists of 13 workers with 7 divisions with production capacity of 300 woks/day. In the printing division, the thinking division, the division of each worker is given a target of 74 woks/day. Meanwhile, for the division that employs 1 worker to process 300 woks/days. Figure 2.b describes the stages of the wok production of the recommendations. The production process consists of 15 workers with 7 divisions with production capacity of 300 woks/day. In the printing division, the grinding division, the division of each worker is given a target of 100 woks/day. Meanwhile, for the division that employs 1 worker to process 300 woks/days.

The pre-work system to get a big bottleneck that is in the first shelter of the printing division has a high pile that is an average of 48 units/day and at the temporary shelter division gets a stack averaging as many as 19 units. The total amount of bottleneck pile that occurred is 76 wok. From the simulation experiment, $25 \%$ of finished goods are not produced. Simulation is an application process building a model of a real system or proposed system, experimenting with the model to explain system behavior, studying system performance or to build new systems according to desired performance [25]. Simulation results from recommendation system get less bottleneck than prefix system. However, to overcome the bottleneck that occurs can be given treatment to the workers to be trained to work more quickly and consistently. In the first shelter of the printing, division shelter has a high pile that is an average of 1 unit and at the temporary shelter 2 that is the sheltered division of the lathe get a pile of wok average of 5 units/day. In some divisions ie division, inspection, inspection and transportation and weighing there is 1 stack average with the percentage of a stack of $3 \%$.

\section{Conclusion}

Based on the research that has been done, it can be concluded that the workload capacity of the worker in the work system is the division of 1.15 with the effectiveness of 9 , the printing division of 1.04 with the effectiveness of 88 , the division of thinking 1.38 with the effectiveness of 117 , the division 1.34 with the effectiveness 113 , the inspection division of 1.05 with 94 effectiveness, the packaging division 1.10 with effectiveness 94 , And the transpenim division 1.13 with the effectiveness of 95 . Then the total number of workers to be employed in each division in the prefix system at the one-workers melting division, the printing press 3 workers, 4 workers' mind divisions, the division division adds 2 workers to 4 workers. For the inspection division of 1 worker. The last two divisions are the weighing and packaging transport divisions of each worker. The simulation results of many pre-loaded items with an average of 76 units of wok with average wok produced 223 units of wok/day. Meanwhile, when producing with a proposed work system, the workflow will be better with an average production of 291 pans/day with a total pan that is stuck for 9 woks.

\section{References}

1. R. Ridha, A. Bakar, C. Nugraha. Usulan Kebutuhan Jumlah Tenaga Kerja di Bagian Water Based PT.X Berdasarkan Analisis Beban Kerja. Reka Integra, Jurnal Online Industri Institut Nasional, 1(2) 52-61 (2013)

2. R. M. Afia, M.E Ranu. Kontribusi Beban Kerja, Disiplin Kerja, Hubungan dengan Teman Sekerja Terhadap Produktivitas Kerja di PT. Viccon Modern Industry. Jurnal Administrasi Perkantoran (JPAP), 1 (3) (2013)

3. W. Adawiyah and A. Sukmawati. Analisis Beban Kerja Sumber Daya Manusia Dalam Aktivitas Produksi Komoditi Sayuran Selada DI CV Spirit Wira Utama. Jurnal Manajemen Organisasi (JMO) 4 ,128-143 (2016)

4. Menpan, "Pedoman Perhitungan Kebutuhan Pegawai Berdasarkan Beban Kerja dalam Rangka Penyusunan Formasi Pegawai Negeri Sipil (Kep. Men. PAN Nomor: $\quad K E P / 75 / M$. PAN/7/2004), Jakarta, Kementerian Pendayagunaan Aparatur Negara Republik Indonesia, (2014).

5. . Hurd, FTE for Definition.Calculations, Examples And System Usage Information For HRMS And GL Budget Purpuses, Colorado, (2004) 
6. J. Hurd, FTE for Definition.Calculations, Examples And System Usage Information For HRMS And GL Budget Purpuses, Colorado, (2004)

7. A. Freivalds, B. Y. Niebels. Methods, Standards, and Work Design. Singapore: McGraw-Hill. (1999)

8. EH. Puspawardhani, MR. Suryoputro, AD. Sari, RD. Kurnia, and H. Purnomo. Mental workload analysis using NASA-TLX method between various level of work in plastic injection division of manufacturing company. Advances in Intelligent Systems and Computing Advances in Safety Management and Human Factors, Orlando (2016)

9. O. J. Sealetsa and A. Thatcher. Ergonomics issues among sewing machine operators in the textile manufacturing industry in Botswana. Work, 38, pp. 279-289 (2011)

10. A.D Sari, M.R. Suryoputro, M.D. Pramaningtyas, P.S Putra and S.B. Maulidyawati. Work Physiology Evaluation of Laundry Workers. IOP Conference Series: Materials Science and Engineering (2016)

11. P.A McQuid, R.L Kolehmainen-Aitken, and N. Forster. Applying the workload indicators of staffing need (WISN) method in Namibia: challenges and implications for human resources for health policy. Human Resources for Health, 11, 64 (2013)

12. D. Bonfim, A.M Laus, A.E Leal, F.M.T Fugulin, R.R Gaidzinski. Application of the Workload Indicators of Staffing Need method to predict nursing human resources at a Family Health Service. Revista LatinoAmericana de Enfermagem, 24 (2016)

13. R. Sharma, R. Singh. Work-related musculoskeletal disorders, job stressors and gender responses in foundry industry. International Journal of Occupational Safety and Ergonomics (JOSE), 20, 363-373 (2014)

14. P. Tandon, A. Tiwari, S. Tamrakar. Implementation of Lean Manufacturing Principles in Foundries. International Journal of Modern Engineering Research (IJMER) IJMER, 4 (2). 46-50 (2014)

15. H. Purnomo. Workload Analysis For Determining The Number Of Employees At Bank Companies. GEMA Jurnal 201. 2068-2076(2015)
16. R. P. Wibawa, Sugiono et R. Y. Efranto. Analisis Beban Kerja Dengan Metode Workload Analisis Sebagai Pertimbangan Pemberian Insentif Pekerja di Bidang PPIP PT Barata Indonesia, Jurnal Universitas Brawijaya, pp. 672-683, (2014)

17. Zhu, X., Zhang, R., He, Z., Chu, F., \& Li, J. FlexsimBased Optimization for The Operation Process of Cold-Chain Logistics Distribution Centre. 5School of Mechanical, Electronic and Control Engineering, 270-278. (2014)

18. OrientPoint. FTE Analysis and Models, Retrived from : http://www.orientpoint.com/FTE.htm (2014)

19. Wu, Hsin-Chieh, and Mao-Jiun J. Wang. "Relationship between maximum acceptable work time and physical workload." Ergonomics 45, no. 4 280-289 (2002)

20. R. M. Barnes, Motion and Time Study. Design and Measurement of Work. Wiley., 1980

21. Karo, G. Karo, and E.Adianto. "Pengukuran Produktivitas Karyawan Dengan Metode Full Time Equivalent (FTE) PT. Astra International Tbk Divisi Astra Motor Penempatan Jakarta Honda Center." JIEMS (Journal of Industrial Engineering and Management Systems) 7, no. 1 (2017)

22. Y. S. Leung, W. K. Wong et L. C. Mak, A simulation analysis of the impact of production lot size and its interaction with operator competence on manufacturing system performance,» Simulation Modelling Practice and Theory 49, pp. 203-214, (2014)

23. W. Novera, Analisis Beban Kerja Dan Kebutuhan Karyawan Bagian Administrasi Akademik Dan Kemahasiswaan Di Tata Usaha Institut Pertanian Bogor, (2010)

24. Hendrayanti, Endang. "Analisis Beban Kerja Sebagai Dasar Perencanaan Kebutuhan SDM." Jurnal LPPM: PARADIGMA 9, no. 01 (2011)

25. Y. G. Sandanayake, F. C. Oduoza et G. D. Proverbs, Systematic Modelling and Simulation Approach For JIT Performance,» Robotics and ComputerIntegrated Manufacturing 24, pp. 735-743, (2008) 